\title{
The Effect of Tiered Training and Self Regulated Learning (SRL) on Teacher Pedagogic Competence of Early Childhood Education in North Maluku Province
}

\author{
Rosita Wondal $^{1,2}$, Maruf Akbar ${ }^{1}$, Asep Supena ${ }^{1}$, Farida Samad ${ }^{2}$ \\ ${ }^{1}$ Department of Early Childhood Education, Jakarta State University, Jakarta, Indonesia \\ ${ }^{2}$ Department of Early Childhood Education, Khairun University, Ternate, Indonesia
}

Email address:

rositawondal@yahoo.co.id (R. Wondal), profdrmarufakbarmpd@gmaol.com (M. Akbar), asupena@unj.ac.id (A. Supena), faridasamad81@gmail.com (F. Samad)

\section{To cite this article:}

Rosita Wondal, Maruf Akbar, Asep Supena, Farida Samad. The Effect of Tiered Training and Self Regulated Learning (SRL) on Teacher Pedagogic Competence of Early Childhood Education in North Maluku Province. International Journal of Vocational Education and Training Research. Vol. 4, No. 1, 2018, pp. 22-27. doi: 10.11648/j.ijvetr.20180401.14

Received: April 22, 2018; Accepted: May 22, 2018; Published: June 19, 2018

\begin{abstract}
The purpose of this study is to determine the effect of tiered training and Self-Regulated Learning (SRL) on pedagogical competence of early childhood education teachers in North Maluku Province. Which training is suitable to be implemented by considering the teacher SRL so as to press the budget and get the maximum results. The results showed that: the influence of tiered training and self regulated learning (SRL) on pedagogic competence of the early childhood teachers in North Maluku Province. Teachers with a high level of self regulated learning (SRL) suitable to follow the advanced training of early childhood, where the requirement for advanced training is higher than the basic training and PAUD SKB training. Thereby to improve pedagogic competence, teachers should follow the tiered training, but take notice to teacher's level of SRL.
\end{abstract}

Keywords: Tiered-Training, Self-Regulated Learning, Pedagogic Competence

\section{Introduction}

Early Childhood Education Teachers are the first teachers at the level of education in schools that play a role in the development of Indonesian human beings. Therefore, early childhood teachers need to have good competence in teaching children (pedagogic competence). Pedagogical competence as "the ability of an individual to use a coordinated, synergistic combination of tangible resources (e.g. instruction materials such as books, articles, and cases and technology such as software and hardware) and intangible resources (e.g. knowledge, skills, experience) to achieve efficiency and/ or effectiveness in pedagogy". The concept of pedagogical competence also tends to be used with the meaning of minimum professional standard, often specified by law, which should raise a person in fulfilling a particular role of the teaching profession. V. A. Slastenin in Sabirova said that the notion of pedagogue professional competence expresses unity of theoretical and practical readiness for fulfilling pedagogical work and characterizes one's professionalism [1]. Saroyan \&
Amundsen in Mirzagitova et al said that necessary that future expert became the subject of own professional development. And, as a result-it is important to organize the solution of a problem of self-development of pedagogical competence when training future teachers [2].

But the reality shows that so far the competence those teachers have based on the results of competency tests in Indonesia in 2015, North Maluku Province get the last ranking of 34 provinces in Indonesia. This is certainly quite apprehensive; on the one hand the Indonesian government has done its best to spend a considerable cost through the training done in stages (gradually) to overcome the problem. The modern educational reality dictates need of transition to new level as well pedagogical training of future teachers [3]. Teachers' efforts in developing themselves to achieve their professionalism can be manifested in their participation in activities in clusters of early childhood which will be influenced by external factors as well as internal from the teachers themselves. Internal factors are closely related to attitudes and behaviors aimed at teachers, such as desire, 
encouragement, willingness and sincerity within the teacher to work to improve their competence. Internal factors are identical to the motivation and commitment of teachers to improve their quality in plenary. It can be through the way the teachers regulate Self-Regulated Learning (SRL) that exist in them.

Rose Mary Papa said that "A self regulated learner is defined as a student who deliberately generates his or her own thoughts, feelings, and actions to achieve his or her learning goals. In addition to self regulations processes, SRL also involves the enactment of specific behavioral strategies" [4]. Zimmerman cited by Bembenutty, revealed that learners, who have self regulated learning (SRL), are able to regulate metacognitive, motivation and behavior in their own learning process in terms of thoughts, feelings and actions to achieve the expected / targeted learning objectives [5]. Persico describes SRL as a cycle process consisting of (1) planning, (2) implementation and monitoring, and (3) self-evaluation [6]. self regulated learning has been able to provide a specific picture of the various components that affect success. [7]

Based on the problems above, the research problems are formulated as follow: are there influence of tiered training and self regulated learning (SRL) on pedagogic competence of the early childhood teachers in North Maluku Province?

\section{Research Method}

The type of research that is used is ex post facto. In this research, the researcher tried to reveal the phenomenon that has happened in the research location that is in West
Halmahera Regency and Ternate City, with data collecting system through secondary data (documentation) with related institutions to know the respondents with the training theyfollowed and the primary data is through the instrument in the form of SRL questionnaire and questions pedagogic competence of early childhood teachers.

The research design used the design of treatment by level (3x2), with the sample consisting of 3 groups with the provision of teachers of early childhood education who have the qualification of two diploma (D2) of early childhood education which have attended the basic education and early childhood education training and as well as following the PAUD SKB training held by the learning activity studio (SKB) and HIMPAUDI organization in North Maluku Province in 2013 - 2015, with a total of 90 teachers (30 teachers of basic training participants, 30 teachers of advanced training participants and 30 teachers attending SKB training). Sampling system is with simple random sampling

\section{Research Finding}

In general, descriptions of data on pedagogic competence which is the result of the training after the early childhood teachers have learning process in three types of training those are advanced training, basic training and PAUD SKB training (learning activity studio). The calculation data include: mean (mean), median, mode, standard deviation, maximal and minimum score in the form of distribution frequency, and they are presented in table 1 below:

Table 1. Description of Data Group Statistics.

\begin{tabular}{|c|c|c|c|c|}
\hline $\mathbf{Y}$ & A1 Advanced & A2 Basic & A3 SKB & $\mathbf{\Sigma B}$ \\
\hline \multirow{6}{*}{$\begin{array}{l}\text { B1 } \\
\text { SRL } \\
\text { High SRL }\end{array}$} & $\mathrm{n}_{11}=10$ & $\mathrm{n}_{12}=10$ & $\mathrm{n}_{13}=10$ & $\mathrm{n}_{10}=30$ \\
\hline & $\Sigma \mathrm{Y}_{11}=416$ & $\Sigma Y_{12}=352$ & $\Sigma Y_{13}=291$ & $\Sigma Y_{10}=1,059$ \\
\hline & $\overline{\mathrm{Y}}_{11}=41.60$ & $\overline{\mathrm{Y}}_{12}=35.20$ & $\overline{\mathrm{Y}}_{13}=29.10$ & $\bar{Y}_{10}=35.30$ \\
\hline & $\sigma_{11}=5.36$ & $\sigma_{12}=3.82$ & $\sigma_{13}=6.14$ & $\sigma_{10}=7.22$ \\
\hline & $\sigma_{11}^{2}=28.71$ & $\sigma_{12}^{2}=14.62$ & $\sigma_{13}^{2}=37.66$ & $\sigma_{10}^{2}=52.08$ \\
\hline & $\Sigma \mathrm{Y}_{11}^{2}=17,564$ & $\Sigma Y_{12}^{2}=12,522$ & $\Sigma Y_{13}{ }^{2}=8,807$ & $\Sigma \mathrm{Y}_{10}^{2}=30,086$ \\
\hline \multirow{6}{*}{$\begin{array}{l}\text { B2 } \\
\text { SRL } \\
\text { Low SRL }\end{array}$} & $\mathrm{n}_{21}=10$ & $\mathrm{n}_{22}=10$ & $\mathrm{n}_{23}=10$ & $\mathrm{n}_{20}=30$ \\
\hline & $\Sigma Y_{21}=297$ & $\Sigma \mathrm{Y}_{22}=310$ & $\Sigma \mathrm{Y}_{23}=315$ & $\Sigma Y_{20}=922$ \\
\hline & $\bar{Y}_{21}=29.70$ & $\bar{Y}_{22}=31.00$ & $\overline{\mathrm{Y}}_{23}=31.50$ & $\bar{Y}_{20}=30.73$ \\
\hline & $\sigma_{21}=4.95$ & $\sigma_{22}=3.56$ & $\sigma_{23}=5.17$ & $\sigma_{20}=4.52$ \\
\hline & $\sigma_{21}{ }^{2}=24.46$ & $\sigma_{22}{ }^{2}=12.67$ & $\sigma_{23}^{2}=26.72$ & $\sigma_{20}^{2}=20.41$ \\
\hline & $\Sigma Y_{21}^{2}=9,041$ & $\Sigma Y_{22}{ }^{2}=9,724$ & $\Sigma Y_{23}^{2}=10,163$ & $\Sigma \mathrm{Y}_{20}^{2}=18,765$ \\
\hline \multirow{6}{*}{$\Sigma \mathrm{A}$} & $\mathrm{n}_{01}=20$ & $\mathrm{n}_{02}=20$ & $\mathrm{n}_{03}=20$ & $\mathrm{n}_{00}=60$ \\
\hline & $\Sigma \mathrm{Y}_{01}=713$ & $\Sigma \mathrm{Y}_{02}=662$ & $\Sigma \mathrm{Y}_{03}=606$ & $\Sigma Y_{00}=1,981$ \\
\hline & $\bar{Y}_{01}=35.65$ & $\bar{Y}_{02}=33.10$ & $\bar{Y}_{03}=30.30$ & $\bar{Y}_{00}=33.02$ \\
\hline & $\sigma_{01}=7.90$ & $\sigma_{02}=4.19$ & $\sigma_{03}=5.66$ & $\sigma_{00}=6.40$ \\
\hline & $\sigma_{01}^{2}=62.45$ & $\sigma_{02}^{2}=17.57$ & $\sigma_{03}^{2}=32.01$ & $\sigma_{00}^{2}=40.93$ \\
\hline & $\Sigma \mathrm{Y}_{01}^{2}=26,605$ & $\Sigma \mathrm{Y}_{02}{ }^{2}=22,246$ & $\Sigma \mathrm{Y}_{03}{ }^{2}=18,970$ & $\Sigma Y_{00}^{2}=67,821$ \\
\hline
\end{tabular}

Inf.:

$\mathrm{A}_{1:}$ Group of teachers who followed advanced training

$\mathrm{A}_{2:}$ Group of teachers who followed basic training

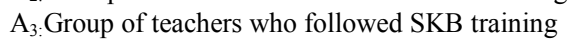

$B_{1}$ : Group of teachers who have high SRL

$\mathrm{B}_{2:}$ Group of teachers who have low SRL

$\mathrm{n}$ : Amount of samples

$\bar{Y}$ : Average score of pedagogic competence result

$\sigma:$ Standard Deviation

$\sigma^{2:}$ Variance 
Before being tested with ANAVA, it was first tested requirement of ANAVA that is normality test and homogeneity test of variance to data that have been obtained, and the result show that sample is normally distributed and come from homogeneous population.

Test of statistical hypothesis in this research done by using variance analysis (ANAVA) $3 \times 2$ and continued with t- test to know the superiority of each group of teacher. Analysis of variance $3 \times 2$ is used to test the main effect and interaction effect of independent variable to dependent variable.

Table 2. Results of ANAVA Analysis.

\begin{tabular}{|c|c|c|c|c|c|c|c|}
\hline \multirow{2}{*}{ Variance Sources } & \multirow{2}{*}{ Dk } & \multirow{2}{*}{ JK } & \multirow{2}{*}{ RJK } & \multirow{2}{*}{ F count } & & \multicolumn{2}{|l|}{ F table } \\
\hline & & & & & & $\alpha=0.05$ & $\alpha=0.01$ \\
\hline Inter groups & 5 & $1,111.483$ & 222.297 & \multirow{2}{*}{\multicolumn{2}{|c|}{$9.209 * *$}} & \multirow{2}{*}{2.839} & \multirow{2}{*}{4.313} \\
\hline Intra groups & 54 & $1,303.500$ & 24.139 & & & & \\
\hline Column (A) & 2 & 286.433 & 143.217 & 5.933 & $* *$ & 3.168 & 5.021 \\
\hline Row (B) & 1 & 312.817 & 312.817 & 12.959 & $* *$ & 4.020 & 7.129 \\
\hline Interaction & 2 & 512.233 & 256.117 & 10.610 & $* *$ & 3.168 & 5.021 \\
\hline Total & 60 & $2,414.98$ & & & & & \\
\hline
\end{tabular}

Info:

$\mathrm{dk}=$ degrees of freedom

$\mathrm{jk}=$ total square

$\mathrm{RJK}=$ average total square

$* *=$ very significant on $\alpha=0,01$

\section{Discussion}

Discussion of research results is based on descriptions of data pedagogic competence and results of hypothesis testing as described previously. Discussion of further hypothesis testing results and will be described as below:

\subsection{Differences of Pedagogic Competence Between Teachers Who Follow the Advanced Training, Basic and PAUD SKB Training}

The first hypothesis proved that the pedagogic competence of teachers who followed the advanced training of early childhood is higher than the teachers who participated in basic training training and PAUD SKB training in North Maluku province, is accepted. Based on Anava Test results is 5.933> 3.168. This can be seen also from the results of pedagogic competence test for teachers who followed the advanced training 35.65 , basic training 33.10 and PAUD SKB 30.30 training.

Based on the results showed that in order to achieve the expected pedagogic competence, the use of the training offered is advanced training because considering the training process in advanced training is very helpful in the development of pedagogic competence of early childhood teachers such as the understanding of early childhood curriculum, the development of six aspects of early childhood ability, learning strategies, and child growth detection, which are not found in basic training and SKB training which become some indicators in assessing teacher pedagogic competence. One of the benefits of training is to increase productivity, improve the quality of work and increase morale, develop skills, knowledge, understanding and new attitudes, and increase knowledge to fit the performance or in accordance with the job. Therefore, the curriculum structure in the training needs to be considered for the development of its competence.
In PAUD SKB training, the training implement several methods include: 1) lectures, 2) Questions and 3) direct practice. In the method of direct practice, it is done during the process of training activities in progress, integrated in the material provided. This is quite different from the advanced training and basic training that has the method include: 1) lecture, 2) discussion, 3) questions, 4) typical study, 5) practice, 6) motivation, 7) energizer and 8) self-reflection. Methods of practice are done in the field at each teacher's agency for 25 working days, so tend to affect the results of pedagogic competence. This is in accordance with the advice of research conducted by Çer that It is suggested that extension of practice period throughout the program, as in Singapore case, may help to overcome some of these problems in a short term [8]. Thus, in the findings of this study, it can be recommended that to improve pedagogical competence of early childhood teachers, advanced training is recommended to be applied.

\subsection{The Interaction Effect Between Tiered Training and Self Regulated Learning (SRL) on Pedagogic Competence of Early Childhood Teachers}

The results of the second hypothesis testing showed that there is a significant interaction effect between tiered training and self regulated learning (SRL) on the competence of early childhood teachers. This is evidenced by the value of Anava obtained, the price $\mathrm{F}_{\text {coun }}>\mathrm{F}_{\text {tab. }}$ on $\alpha=0.05(10.610<3.168)$.

This implies that the value of pedagogic competence earned by early childhood teachers in all three training groups, and the value obtained with each group of data based on the level of self-regulated learning (SRL) have a mutually supportive interaction relationship. The more often teachers follow the training activities, with a high level of self-regulated learning (SRL), the higher the pedagogic competence of the teacher. In addition, other factors are also the motivation of the participants. this is in accordance with research conducted by 
the Pedrosa, et al that motivation factors can influence self regulated learning from within a person. [9]. Self regulation in aspect reaction and reflection is the stage when individuals make cognitive judgments and evaluations regarding; showing effective reaction, insistence, giving up, choice making, and evaluating content. It is the time when s/he evaluates her/his task. In short, it is the time that the individual assesses himself/herself about whether there is a difference between the target and the performance he/she has demonstrated in the beginning [10]. This is because teachers play an important role in the provision of education and thus significantly affect the quality of education. The following is an overview of the interaction result between tiered training and Self-Regulated Learning (SRL) on the results of competence of early childhood teachers in North Maluku Province.

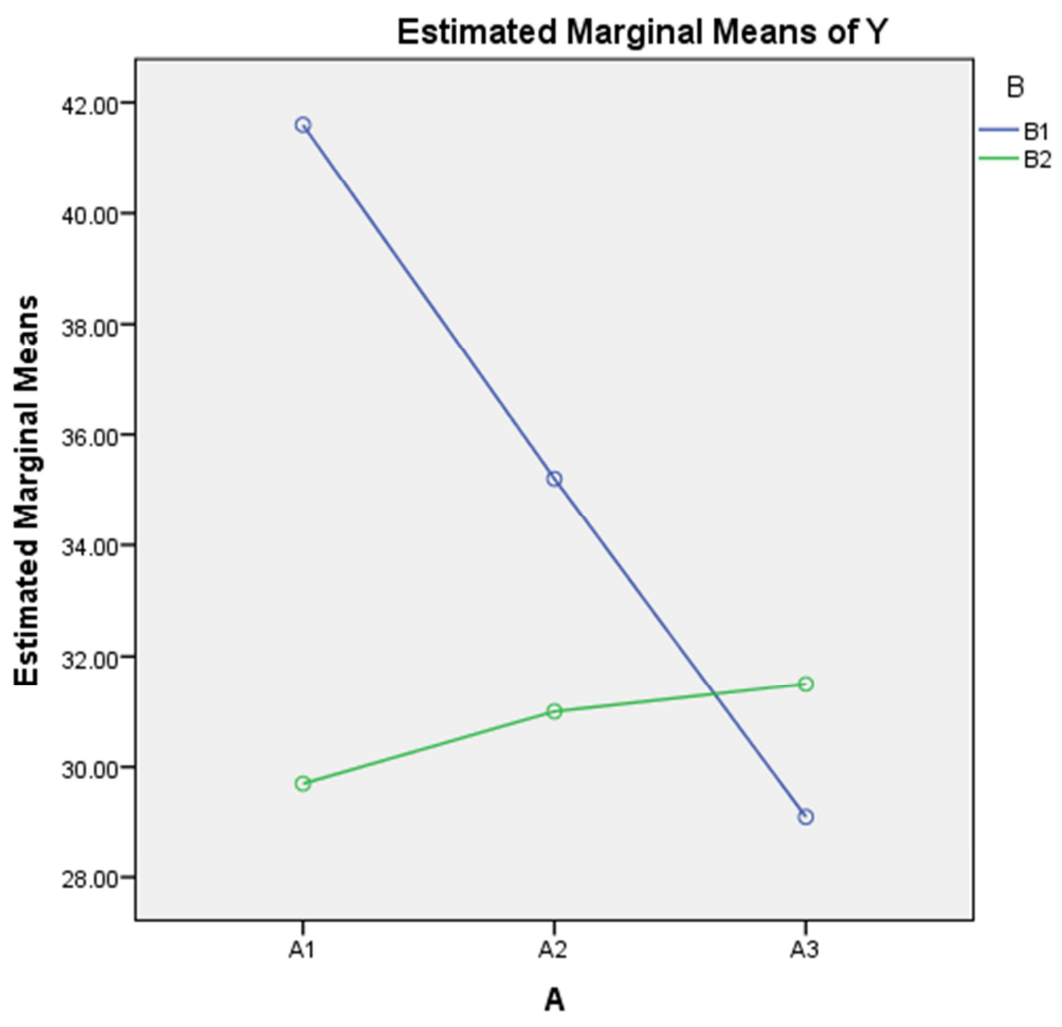

Figure 1. Visualization of interaction between tiered training and SRL on pedagogical competence.

\subsection{Differences of Pedagogic Competence Between Teachers Who Followed Advanced Training and Basic Training with High SRL (A1B1 and A2B1)}

The results of the third hypothesis testing which showed that the pedagogic competence of teachers with high self-regulated learning (SRL) who followed the higher advanced training with teachers with high self-regulated learning (SRL) who followed the basic training is accepted. This is evidenced by the value because $\mathrm{q}_{\mathrm{h}}>\mathrm{q}_{\mathrm{t}}$. This means that there is a difference of pedagogic competence of teachers with high SRL who followed advanced training with teachers with high self-regulated learning (SRL) who followedbasic training, because $\mathrm{q}_{\mathrm{h}}=7.95>\mathrm{q}_{\mathrm{t}}=4.920$ and this can also be seen from the teacher pedagogic competency with high self-regulated learning (SRL) who followed advanced training that is 41.60 with high SRL following the basic training is 35.20.

This implies that teachers who followed advanced training tend to be more trying to activate and control their thoughts, behaviors and feelings, in order to achieve a learning objective compared to teachers who followed basic training. By remembering that in advanced training, it emphasizes more on how teachers are more active for make the tasks when the training is applicative in the learner in early childhood. Thus, the teacher is increasingly trying to find sources that exist in the environment so that the teacher's willingness to learn better and keep trying to understand the content of material provided.

This is supported also by research from Toraman et al, The result was established that the thought (on the part of the teaching candidates) that teacher training education contributed positively to the acquisition of class management skills, tended to decrease the attitude that this type of education was unnecessary [11].

Advanced training is more emphasized on the understanding and development of the concept applied, meanwhile the basic training in the training tends to be only on the introduction of the concept alone. It is suspected that teachers gain a different understanding of the content provided, thus affecting the pedagogic competence of the training group the teacher.

Based on the findings, apparently, teachers with high SRL who followed the basic training have not been able to meet the expectations to improve pedagogic competence of early childhood teachers, when compared with teachers who 
followed the advanced training.

\subsection{Differences of Pedagogic Competence Between Teachers Who Follow Advanced Training and PAUD SKB Training with High SRL (A1B1 and A3B1)}

The result of the fourth hypothesis test which showed that the competence of teachers with high self-regulated learning (SRL) who followed advanced training is higher than teachers with high self-regulation learning (SRL) who followed SKB training is accepted, because $\mathrm{q}_{\mathrm{h}}>\mathrm{q}_{\mathrm{t}}$. This means that there is a difference of pedagogic competence of teachers with high self-regulated learning (SRL) who followed advanced training with teachers with high self-regulated learning (SRL) who followed SKB training, because $\mathrm{q}_{\mathrm{h}}=13.935>\mathrm{q}_{\mathrm{t}}=4.920$. It can also be seen from the average result of teacher's competitiveness with high self-regulated learning (SRL) who followed advanced training that is 41.60 with high self-regulated learning (SRL) who followed SKB training is 29.10 .

This implies that teachers who followed advanced training tend to be more trying to activate and control their thoughts, behaviors and feelings, in order to achieve a learning goal compared with teachers who followed SKB training tend to be passive with tasks that are less challenging the teacher to try more so they are encouraged by the pattern that was proclaimed as a result of following the training. This is in line with the opinion of Karim et al, the intention of the training programs must also aim at producing self-sufficient teachers. They must design their materials in a way that would spell equipped teachers, capable of developing own lesson plans, classroom materials and so on. Moreover, to bring sustainable development, they must facilitate teachers to retain what they have learned in the training program [12]. A self-regulated learner can independently and effectively plan for learning, choose and use appropriate learning strategies and reflect and monitor learning progress. Self- regulated learning, for learners in general and for distance learners in particular, is inevitable for effectual learning process. [13].

Based on the findings of this hypothesis, it was tested that teachers with high SRL who followed the PAUD SKB training have not been able to meet expectations for increaseing pedagogic competence. Advanced training is recommended to improve pedagogic competence of early childhood teachers.

\subsection{Differences of Pedagogic Competence Between Teachers Who Followed Basic Training and PAUD SKB Training with High SRL (A2B1 and A3B1)}

The results of the fifth hypothesis testing showed that the pedagogic competence of teachers with high self-regulated learning (SRL) who followed the basic training is higher than teachers who attended the PAUD SKB training. This is in accordance with accepted tuckey test results. The results obtained are $\mathrm{q}_{\mathrm{h}}>\mathrm{q}_{\mathrm{t}}$. This means that there is a significant difference in pedagogic competence of teachers with high self-regulated learning (SRL) who followed basic training with high self-regulated learning (SRL) teachers who followed the PAUD SKB training, because $\mathrm{qh}=7.578>\mathrm{q}_{\mathrm{t}}=$ 4.920. It can also be seen from the pedagogic competence of teachers who have high self-regulated learning (SRL) who followed the basic training is 32.20 and those with high selfregulated learning (SRL) who followed the PAUD SKB training is 29.10 .

The difference in outcomes between teachers who followed basic education and PAUD SKB does not only lay the training content of the training provided in the training activities but it also lies in the strategy used in the process and post training and time given to teachers. Teachers who followed PAUD SKB training tasks that provide less challenging tasks are only limited to direct practice at the time of training activities with relatively little time. When compared with teachers who followed basic education training and those who do field activities. This is in line with the opinion of Ulla, Admittedly, teacher training and other professional development programs are an important element for preparation and qualifications of teachers to teach in the classroom. Giving the teachers the right training programs they need is vital for the education reform in the country [14].

This follow-up is related to the self-employment assigned for 25 days in the field. Moreover, an effective training depends on how well the training program is designed; it should consider learning theories, specific learning objectives, trainee characteristics, learning processes and training techniques.

Based on the findings of this hypothesis, it turns out that teachers with high SRL who followed the basic training meet expectations in improving teacher pedagogic competence when compared with the PAUD SKB training.

\section{Conclusion}

Based on research data, it can be concluded that there is the influence of tiered training and self regulated learning (SRL) on pedagogic competence of the early childhood teachers in North Maluku Province. Teachers with a high level of self regulated learning (SRL) suitable to follow the advanced training of early childhood, where the requirement for advanced training is higher than the basic training and PAUD SKB training. Thereby to improve pedagogic competence, teachers should follow the tiered training, but take notice to teacher's level of SRL.

\section{Acknowledgements}

The author thanks to the financial support for the research conducted by institution managing education fund (LPDP) Indonesia (process N. PRJ-1523/LPDP.3/2017).

\section{Refferences}

[1] Sabirova Elvira G. Pedagogical Guest Room as an Educational Form of Students' Pedagogical Competence Development International Journal of Environmental \& Science Education, 2016, 11 (6), 1059-1064, 2016, p. 1060. 
[2] Mirzagitova Alsu Linarovna \& Linar Gimazetdinovich Akhmetov, Self-Development of Pedagogical Competence of Future Teacher, International Education Studies journal; Vol. 8 , No. 3; 2015 ISSN 1913-9020 E-ISSN 1913-9039 Published by Canadian Center of Science and Education, 2015. p 114.

[3] Mirzagitova Alsu Linarovna \& Linar Gimazetdinovich Akhmetov, Self-Development of Pedagogical Competence of Future Teacher, International Education Studies journal; Vol. 8, No. 3; 2015 ISSN 1913-9020 E-ISSN 1913-9039 Published by Canadian Center of Science and Education, 2015. p 114.

[4] Papa Rosemary, Media Rich Instruction, USA: Springer Cham Heiberg, 2015, p. 22.

[5] Hafer Bembenutty, Marie C. White

DevelohingSelf-Regulation of Learning and Teaching Skills Among Teachers Candidates. (Shringer Dordrecht Heidelberg New York London (C) The Author (s) 2015.

[6] Persico Donatella, The Interplay Between Self-Regulated Professional Learning And Teachers' Work-Practice. Procedia - Social and Behavioral Sciences 191, 2015. p. 2481-2486.

[7] Sunawan, Beberapa Bentuk Perilaku Underachievement dari Perspektif Teori Self Re-gulated Learning, See discussions, stats, and author profiles for this publication at: https://www.researchgate.net/publication/307681306, February 2016 p. 129.

[8] Çer Erkan \& Ekrem Solak, Examining High-performing Education Systems in Terms of Teacher Training: Lessons Learnt for Low-performers, Journal of Curriculum and Teaching Vol. 7, No. 1; 2018. P. 48.
[9] Pedrosa Daniela, José Cravino, Leonel Morgado, Carlos Barreira, Self-Regulated Learning in Higher Education: Strategies Adopted by Computer Programming Students, See discussions, stats, and author profiles for this publication at: https://www.researchgate.net/publication/305000869, July, 2016, p 594.

[10] Çetin Barış, The Influence of Pintrich's Self-regulated Learning Model on Elementary Teacher Candidates in a Life Science Course, Journal of Education and Training Studies Vol. 5, No. 8; August 2017 ISSN 2324-805X E-ISSN 2324-8068, 2017, p 31 .

[11] Toraman Cetin, Hasan Aydin \& Ozgur Ulubey, Exploring Teacher Candidates' Attitudes towards Pedagogical Teacher Training Based on Different Variables, International Education Studies; Vol. 9, No. 9; 2016 ISSN 1913-9020 E-ISSN 1913-9039, 2016. p. 84.

[12] Karim Abdul, Abdul Rashid Mohamed, Shaik Abdul Malik Mohamed Ismail, Organized Hypocrisy in EFL Teacher Training Programs, International Journal of Instruction, April 2018 • Vol. 11, No. 2 e-ISSN: 1308-1470 • www.e-iji.net, 2018 p. 446.

[13] Ambreen Munazza, Ambreen Haqdad, Wajid A. Saleem, Fostering Self- Regulated Learning Through Distance Education: A Case Study Of M. Phil Secondary Teacher Education Program Of Allama Iqbal Open University, Turkish Online Journal of Distance Education-TOJDE July 2016 ISSN 1302-6488 Volume: 17 Number: 3 Article 9, 2016, p 120.

[14] Mark Ulla B, In-service Teachers' Training: The Case of University Teachers in Yangon, Myanmar, Australian Journal of Teacher Education, vol. 43. 2018. p. 75. 